IRA-International Journal of Management \& Social Sciences

ISSN 2455-2267; Vol.04, Issue 03 (2016)

Pg. no. 512-525

Institute of Research Advances

http://research-advances.org/index.php/RAJMSS

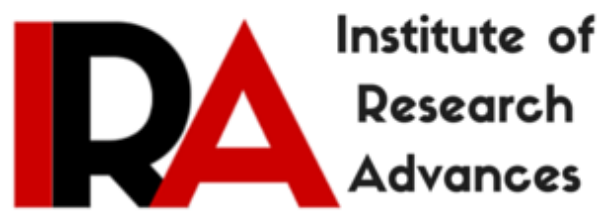

\title{
Role of Handicrafts in Economic Development: A Case Study of Carpet Industry of India
}

\author{
Razia Bano \\ Research Scholar, \\ Department of Geography, A.M.U, Aligarh, India.
}

Type of Review: Peer Reviewed.

DOI: http://dx.doi.org/10.21013/jmss.v4.n3.p1

How to cite this paper:

Bano, R. (2016). Role of Handicrafts in Economic Development: A Case Study of Carpet Industry of India. IRA-International Journal of Management \& Social Sciences (ISSN 2455-2267), 4(3), 512-525. doi:http://dx.doi.org/10.21013/jmss.v4.n3.p1

(C) Institute of Research Advances

\section{(cc) EY-NC}

This work is licensed under a Creative Commons Attribution-Non Commercial 4.0 International License subject to proper citation to the publication source of the work.

Disclaimer: The scholarly papers as reviewed and published by the Institute of Research Advances (IRA) are the views and opinions of their respective authors and are not the views or opinions of the IRA. The IRA disclaims of any harm or loss caused due to the published content to any party. 


\section{ABSTRACT}

Handicrafts industry of India has a great potential in economic development of the country. The present study is an attempt to assess the potential of carpet industry in India. Indian handmade carpet of handicrafts industry is perhaps the only sector over in rural India that almost 100\% export oriented and providing direct employment to the millions, generating opportunities to rural unemployed artisans. At present, carpet sector is contributing US\$ 932 million from export to the government exchequer and providing livelihood over and above to the million weavers and artisans. Indian handmade carpets has recognized worldwide for its elegant design and vibrant color craftsmanship. Present study is an attempt to show the potential of handmade carpet industry of India in accelerating the growth and development of Indian Economy. The present study is based on secondary data collected through the reports from textile ministry, various organization and magazines. The data has analyzed on the basis of simple method and presents by charts, table and diagram.

Key Words: Handicraft industry, carpet industry

\section{Introduction}

The handicrafts sector is the most decentralized and unorganized and unorganized sector of the Indian Economy, and is among India's the most important source of foreign exchange earners. In India, the handicrafts are not merely the industry but the produce is viewed as a creation that symbolizing the inner desire and fulfillment of the community. The Indian craft council points out that no Indian craft is purely decorative. The Indian handicraft item is categorized such as metal ware, pottery, mats, wood-work or weaving. It fulfills a positive need in the daily life of people and also acts as a vehicle of self-expression. In ancient India, the crafts have no division between decorative, artistic objects and those made for everyday use. The handicrafts sector is a home based industry which requires minimum expenditure, infrastructure or training to set up. It uses existing skills and locally available materials. Inputs requires in it can easily be available and these are more in terms of product adaptation than expensive investment. The most important character of the handicrafts is that does not disturb the cultural and social balance of either the home or the community. The agricultural artisans and pastoral communities are depend on their traditional crafts skills as a secondary source of income in times of drought, floods, famine and lean harvest. Their skills in weaving, basket making and embroidery are naural means to social and financial independence. The term was used as "Craft" has articulated as late 1989 by the report of task force on handicrafts for the VIII Five year plan. The definition of handicrafts given by task force is 'Handicrafts are items made by hand, often with the use of simple tools, and are generally artistic and / or traditional in nature. They include objects of utility and objects of decoration'

The handicrafts sector plays a major role in the economic development to the nation. The multifaceted contribution of handicrafts impacts greatly in the development of country, region or people. The handicrafts sector contains the great potential in strengthening and development of economy of the country in terms of foreign earner as well as employment generation.

\section{The Contribution of Handicrafts}

The Handicraft sector occupies a pivotal role in the country's economy as it contributes significantly employment export earning and generation. Handicrafts were traditionally considered a cottage industry in India.

There are myriad of handicraft tradition in India, which depend on social, economic and regional factors. The present status of India owes much to the rich craft traditions of the past. Most of the handicraft continues to flourish due to their utility, availability to the common people and popularity in local as well foreign markets. There is a great demand for rich brocades and zari work. The stock of saris 
ranges from Banarasi to Kanchivaram. There is a profusion of materials available to the consumers these days. There is a huge domestic market for a utilitarian craft items such as bedcovers, tablemats, garden pots, barss and cabinets, jute and coir items etc. The demand of decorative item such as traditional wall hangings, silver cutlery, brass pots, traditional paintings, wood and stone sculpture etc. is also on the rise in India and abroad. In spite of absence of royal patronage, contemporary handicrafts tradition have acquired the mantle of small-scale and cottage industry. Some of the sector within the handicarfts industry have even become full scale large industries like carpet weaving, traditional textile (Banarasi silk sari, Chickenkari etc.), gem cutting and polishing, jewellery making, gems and jewellery, leather products, jute products etc. are some industries, which are mounting with great pace.

The intricate design of carpet attracted the world markets. The weavers weaved the magical carpets in the way that the design turns into the ideas about the world and social relation into the form of physical objects only by exploring this process (Forty, 1986).

Table 1 shows the export performance of Indian Handicrafts since 1998-2014. The total value of 7157.64 (Rs. Crore) of handicrafts has been exported from India of in the year 1998-99. The value export item of Indian handicrafts rose magically in the year 2013-14. It is very clearly shown in the figure (1) that it performance reached ever high in the year 2013-14.

Table1.Export of Handicraft 1998-2012(Rs. in Crore)

\begin{tabular}{|c|c|}
\hline Year & Export of Handicrafts (Rs. In Crore) \\
\hline 1998-1999 & 7157.64 \\
\hline $1999-2000$ & 8105.63 \\
\hline $2000-2001$ & 9270.5 \\
\hline 2001-2002 & 9205.63 \\
\hline 2002-2003 & 10933.67 \\
\hline 2003-2004 & 12765.18 \\
\hline 2004-2005 & 15255.9 \\
\hline $2005-2006$ & 17276.71 \\
\hline $2006-2007$ & 16117.38 \\
\hline 2007-2008 & 12580.74 \\
\hline 2008-2009 & 10891.85 \\
\hline 2009-2010 & 11224.27 \\
\hline 2010-2011 & 9592.73 \\
\hline 2011-2012 & 12975.25 \\
\hline $2012-2013$ & 17970.12 \\
\hline 2013-2014 & 31909.24 \\
\hline
\end{tabular}

Source: Ministry of Textile, Government of India 


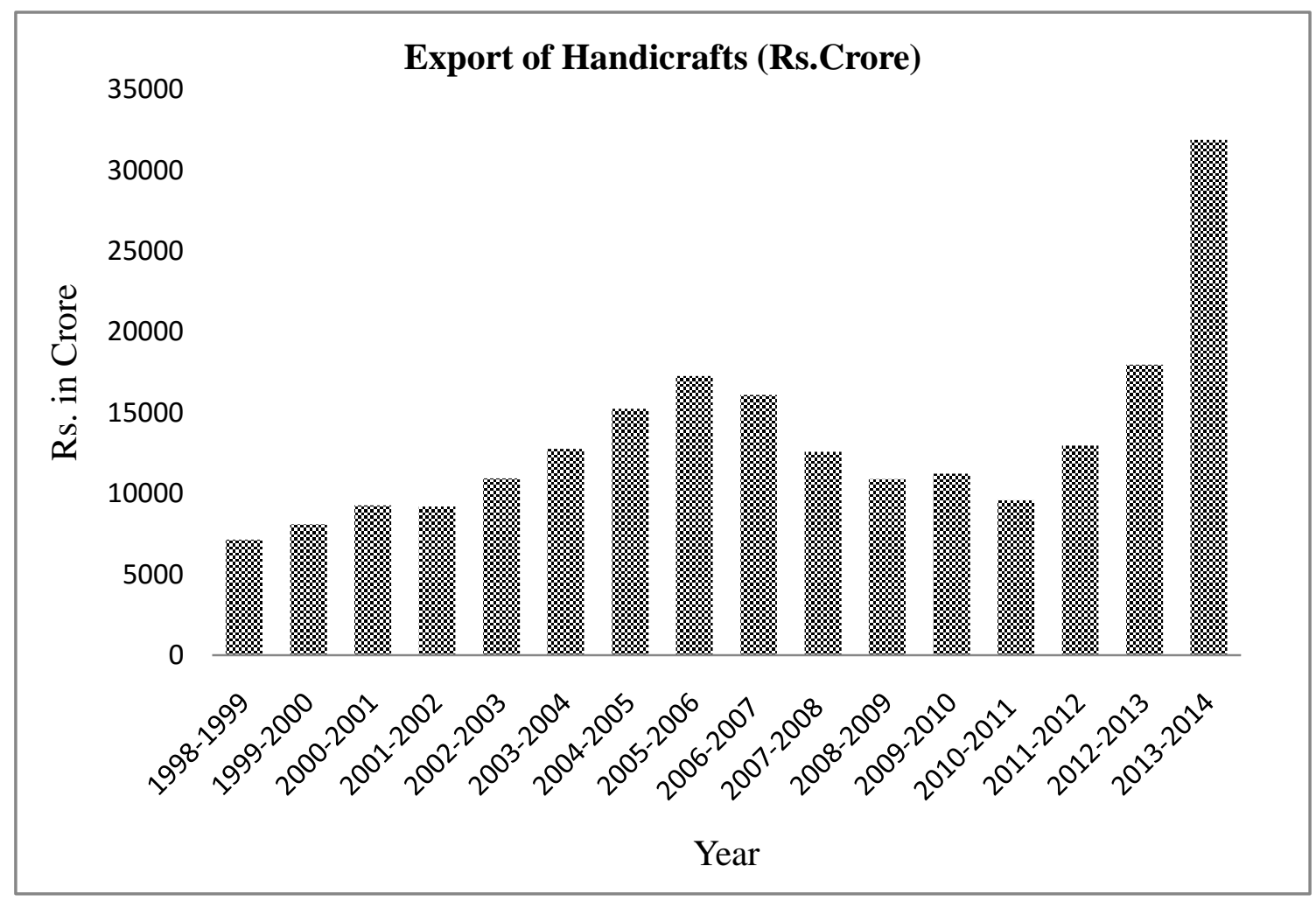

Source: Ministry of Textile, Government of India

Fig.1Export of handicrafts from the year 1981-99 to 2013-14

\section{Objectives of Study}

The term of Indian Handicraft has used for the very vast range of items. The present paper is an attempt to examine the role of handicraft industry in economic development being as a case study of carpet industry. It is an effort to examine the carpet industry's contribution in the economic development of the country.

\section{Methodology and Database}

The present paper is based on secondary source of information. Secondary data have collected through the published and unpublished source such as district industrial centers (DIC'S), office of Carpet Export Promotion Council (CEPC), circulars and magazines published from various department of India .Data have been analyzed through simple percentage method and showed by statistical diagrams.

\section{Review of Literature of Carpet Industry}

Indian Carpet Industry is rural based handicrafts industry has been one of the most important industry in India that is contributing immensely to the country's foreign exchequer through exports and employees million of workers that helps immensely in the economic development of the country. Indian handmade carpet sector of cottage industry is perhaps the only sector over in rural India that is almost 100\% export oriented and providing direct employment to the millions, generating opportunities to rural unemployed artisans. At present, carpet sector is contributing US\$ 932 million from export to the government exchequer and providing livelihood over and above to the million weavers and artisans. India's heritage of handmade carpet weaving has been recognized worldwide for its elaborate design, subtle elegance, and exquisite vibrant colors craftsmanship (Carpet Export Promotion Council Magazine, 2013). Carpet 
Industry is traditional and well established industry in India. Delectated Indian carpets are not only part of bounteous life style in modern times but also reflect eternal blend of nature, culture and art. The intricate weaving of carpet created by 3 millions weavers, this industry plays an essential role in employment and income generation as well as foreign exchange earnings. Carpet industry has been dealt by various scholars from time to time. This sector has been the thrust of study of different countries it has studied from different dimension in each region. The countries like Iraq, Iran, Afghanistan, and Turkey have taken it variedly at broader sense of socio economic, because these countries are the place of origin of carpet. Country like America, Germany and Canada dealt it broadly in terms of economic development because these countries are importing countries instead of manufacturing.

There are some selected literature has reviewed for this paper. Since this industry is rural based, it also lead to balance regional growth.

Singh (1979), in his paper explains how organizational structure is connected with entrepreneurial activity and what sort of actively determines entrepreneurial success and economic development. Carpet industry has spread many parts in India but Bhadohi carpet industry is the leading one and the area known as "Bhadohi Mirzapur belt". The manufactured carpet of Bhadohi is luxuriant items to sell into world market at greater price and played a big role in economic development of Bhadohi.

Sanjay (1982) stated that carpet weaving is the major cottage industry in India and employee thousands of artisans. He added that Bhadohi-Mirzapur belt in Eastern Utter Pradesh contributing the bulk of production roughly $80 \%$ while other major producing centers in India are J\&K, Agra, Jaipur, Amritsar, and Gwalior but contribute very less proportion of the rest of the production and employment in the industry. According to him, the fortune of carpet industry depends on the behavior of international market. He further added that impact of carpet industry on the economic development can be seen into two levels that is regarding the balance of payment and employment generation. Industry makes a substantial positive contribution to the balance of payment at a time when the trade deficit is making demand on the country's capacity and another level is 50-60 percent labour content in the carpet production contribute to employment and exerts an upward pressure on wages, helping in the development of economically backward regions of the country.

Attfield (1994) deals in his paper the nature and characteristics of the tufted carpet. It shows that the boosting growth of tufted carpet in U.K during 1970's. It emphasized on the intricate pattern of its design colour combination and weaving style.

Pattoa (1997) wrote about the entrepreneurs and workers of the Datoa, Gorgea. Mechanization process in the carpet industry revolutionized and revitalized the American Carpet Industry .It wrote that the tufting process of carpet manufacturing is a kind of "Second Industrial revolution "in the Dalton area. This paper shows the per capita income of industry labour. This paper highlights only the economic aspect of carpet industry.

The overall literature that is referred in the study has covered the socio economic nature of carpet industry. The present study is the concern to evaluate the export potential of carpet industry and its role in the economic development.

\section{History of Carpet Industry in India}

In India, Carpet does not a part of culture but it is an act of importation. This art is a kind of migrated art from the Persian and turkey by the Mughals in India. This intricate and sophisticated art has become the part and parcel of Indian culture since then. It provides the finest example of how a domestic industry practiced at home can be transported to a full established and organized industry, from the safe confines at the home where the carpet was weaved jointly by all the family members, this beautiful piece of 
handicrafts has transformed to the industry of mass scale production. The certainty of origin of carpets would always continue to be shrouded in mystery. However it is definitely out of debate that woven forms of floor coverings were present in Neolithic age in7000 BC(www.carpetandrugspedia.com) In India, carpet industry does not originated as a part of tradition, but as an act of importation by Mughal emperors.(carpet export promotion council news, 2013).It is believed that first Mughal emperor Babar(1526-30) imported carpet from Turkey and Persia to India .It dates back to $16^{\text {th }}$ century where Mughal established the art of carpet weaving continued to spread and survive in India under the patronage of Indian nobility. With the ruin of Mughal empire Indian handicraft faced a set back during $19^{\text {th }}$ century. Local carpet workshop was governed by English and European countries. At the great London Exhibition in 1851,Indian handmade carpet received the world attention and appreciation for the first time for the acceptable quality, oriented pattern, fine weavers and rich color combination (Gito and Kumar 2011). In the post British period, indigenous industry started flourishing in different parts of the country. Each region is engaged in making different kind of carpet with variation in materials9silk, wool etc.), design, color and quality .On the basis of quality of wool used in the production the feel of carpets differ. Northern region of carpets are soft and shiny while southern region carpets are opaque and rough.

\section{Region of Carpet Making in India}

The variety of carpet has weaved in the different regions. The different types of carpets are hand-knotted, tufted woolen carpets, pure silk carpets, Persian carpets, Iranian carpets. Carpet Industry has spread some states in India such as Uttar Pradesh, Kashmir, Rajasthan, Haryana, Punjab, Andhra Pradesh, Himanchal Pradesh, Madhya Pradesh and Gujarat.

\section{i. Carpet Industry in Uttar Pradesh}

Shahjahanpur, Mirzapur, Bhadohi, Khamaria and Agra are main hubs for carpet Industry in Uttar Pradesh. During British rule growing demand outside the country encouraged this carpet manufacturing activity. Now-a-days Jute and cotton is used. Carpets made are of medium quality and on an average of about 60 knots per square inch is applied. Shahjahanpur is also well known for luxurious carpets. The designs are beautiful, with geometrical patterns generally in black on a maroon background. Agra is the traditional center of carpet weaving from the period of Mughals. Agra is specialized in the use of silk mixed with woolen yarn. Designs resembles to that of Persian style. The weavers of the Mirzapur-Bhadohi region are renowned for their versatility by weaving carpets of practically any design, including the Old Persian ones that are in great demand

\section{ii. Carpet Industry in Kashmir}

Kashmir is famous for its fine quality hand knotted carpets, which are expensive and considered as lifelong investment. An average piece is made with about 324 knots per square inch. Persian culture influenced the Kashmiri carpet for quite a long time, but gradually the Kashmiri Carpet industry has acquired an indigenous character. Kashmir has developed some of its own designs based on, the traditional paisley, shawl patterns, leaves and flowers. In Kashmir, Talim method is used to train craftsmen. Wool and silk is used for making carpets. The number of knots on the back of the carpet indicates the quality. Bokhara hand knotted carpets are one of the finest with about 120-500 knots in a square inch. The deep pile of Indian hand knotted carpets comes in magnificent colors, with designs which are oriental, exotic and uniquely modern. In Kashmir this trade is passed from one generation to the next. During cold winter when tourism business ends, they market it personally by approaching urban cities like Delhi on a door to door basis. 


\section{iii. Carpet Industry in Rajasthan}

Rajasthan is also known for making namadha that is appliquéd, printed or embroidered. Rajasthan made carpets shows hunting patterns with trees and floral motifs. Jaipur and its adjacent districts is the major manufacturing centers in Rajasthan that share a substantial part (15 percent) of total carpet manufacturing from India. The rulers of Jaipur took a keen interest in patronizing the carpet making activity. They were fond of collecting Persian and Mughal carpets. The carpet industry in Jaipur mainly started flourishing in the mid 19th century. In that period, carpet making was introduced as a jail craft. Rajasthan carpet industry is more quality sensitive and designs are more emphasized. Results of technology implementation were remarkable in terms of revenue and other operational aspects. Centers like Bikaner, Jaipur and Ajmer are the main places for beautiful carpets. Hand knotted carpets are manufactured with floral or angular motifs. These carpets are known for their high quality of craftsmanship and colorfastness, which makes it more durable.

\section{iv. Carpet Industry in Punjab}

Punjab has ancient tradition of weaving cotton durries. Durries are made with the use of comb-like iron fork called "punja" which means hand. It is used to heat the waft yarn to fix up in woven structure. Carpets from the Punjab and Haryana are woven in traditional stripes as well as with stylized birds, animals and human forms, usually used as motifs. Punjab also uses the talim method, which owes the development of the carpet industry to Maharaja Ranjit Singh, who conquered Kashmir. Most commonly mouri designs are used in Punjab. Traditionally, vegetable and mineral dyes like indigo, madder, turmeric, henna were used, however now chemical dyes are highly used. Chemical bath treatment is applied on carpets for a high luster.

\section{v. Carpet Industry in Andhra Pradesh}

Masulipatnam, Elluru and Warangal are the prominent centers for carpet manufacturing in Andhra Pradesh. In Masulipatnam, patterns used are named after the fruits and flowers like babul, guava, ambarcha etc. Also the main designs called by the name of famous patrons for example Nurjaha, Farsi, and Shah Navaz. More often, combination of blue and green with soft yellow and pastel shades is used. The carpets of Elluru and Warangal are the pride of Andhra Pradesh and have a strong local flavor. The carpet weaving at Warangal is done on a large scale because of ease to access cotton. Handspun wool and jute thread are used. The design are again here of Indo-Persian origin. Images are in deep green and orange colors while off-white background is used.

\section{vi. Carpet Industry in Himachal Pradesh}

Sheep and goat rearing is a very common occupation of many villagers in Himachal Pradesh who are also engaged in blanket weaving texturing. Carpets in Himachal have magnificent designs and durable texture. Mainly carpets of these areas are made in pure wool and for durries cotton is used. Many Tibetan craftsmen are engaged in weaving woolen carpets, as a result motifs are influenced by Tibetan tradition and culture. Designs of birds, dragon, lion and swastika are popular. Threads of ground color are used.

\section{Export Potential of Indian Carpet}

The Indian Carpet Industry is vibrant and has considerable potential for growth and development of Indian Economy. It is a labour intensive industry and has potential to provide large scale employment to rural and unemployed youths, besides being an important source of foreign exchange earnings for the country. The Indian Carpet Industry is cottage and primarily a rural based industry. Indian handmade a carpet has showed the ever increasing growth since 6 decade from 1961-62 to 2011-12. The table 2 shows 
that the export of carpet in the year 1961-61 to the world was recorded 4.42 (Rs. Crore). In 1971-72 this number increased to 13.69 (Rs. Crore).It further recorded the value of export was 157.66 ( Rs. Crore) in the year 1981-82 .In 1991-92, the value of carpet export recorded 992 (Rs. Crore). The value of export suddenly increased in the year 2001-2002. The value of export increased in this year was recorded 1642.26 (Rs. Crore). The year 2011-12 shows the ever increase value of export that is 3853.54 (Rs. Crore). This increase of value shoved the potential of export of carpet in the world market. The carpet industry showed its resistance to compete the world stiff competition in the era of competition. This steep increase in export value has possible due to the introduction of mechanized weaving and government concern to provide aid to this industry. It is highly encouraging fact that it contributes the great value of export items. Carpet industry is the only industry that goes totally for export in spite of being in the category of cottage and handicraft industry. The ever increasing growth performance of this sector shows the high potential of sustainability to the world competitive market. Carpet industry proved its efficiency of sustenance in the globalization period where number of Indian craft lost their ground. They keep remaining the aesthetic value of Indian art to the global market.

Table 2 The decadal export performance of carpet of India in terms of value ( Rs. In crore) 1961-2012

\begin{tabular}{|l|r|}
\hline \multicolumn{1}{|c|}{ Year } & \multicolumn{1}{|c|}{ Export (Rs. in Crore) } \\
\hline $1961-62$ & 4.42 \\
\hline $1971-72$ & 13.69 \\
\hline $1981-82$ & 157.66 \\
\hline $1991-92$ & 992 \\
\hline $2001-2002$ & 1642.26 \\
\hline $2011-2012$ & 3853.54 \\
\hline
\end{tabular}

Source: Ministry of Textile, Government of India.

Fig.2 Decadal export performance of Indian carpet from year 1961-62 to 2011-12

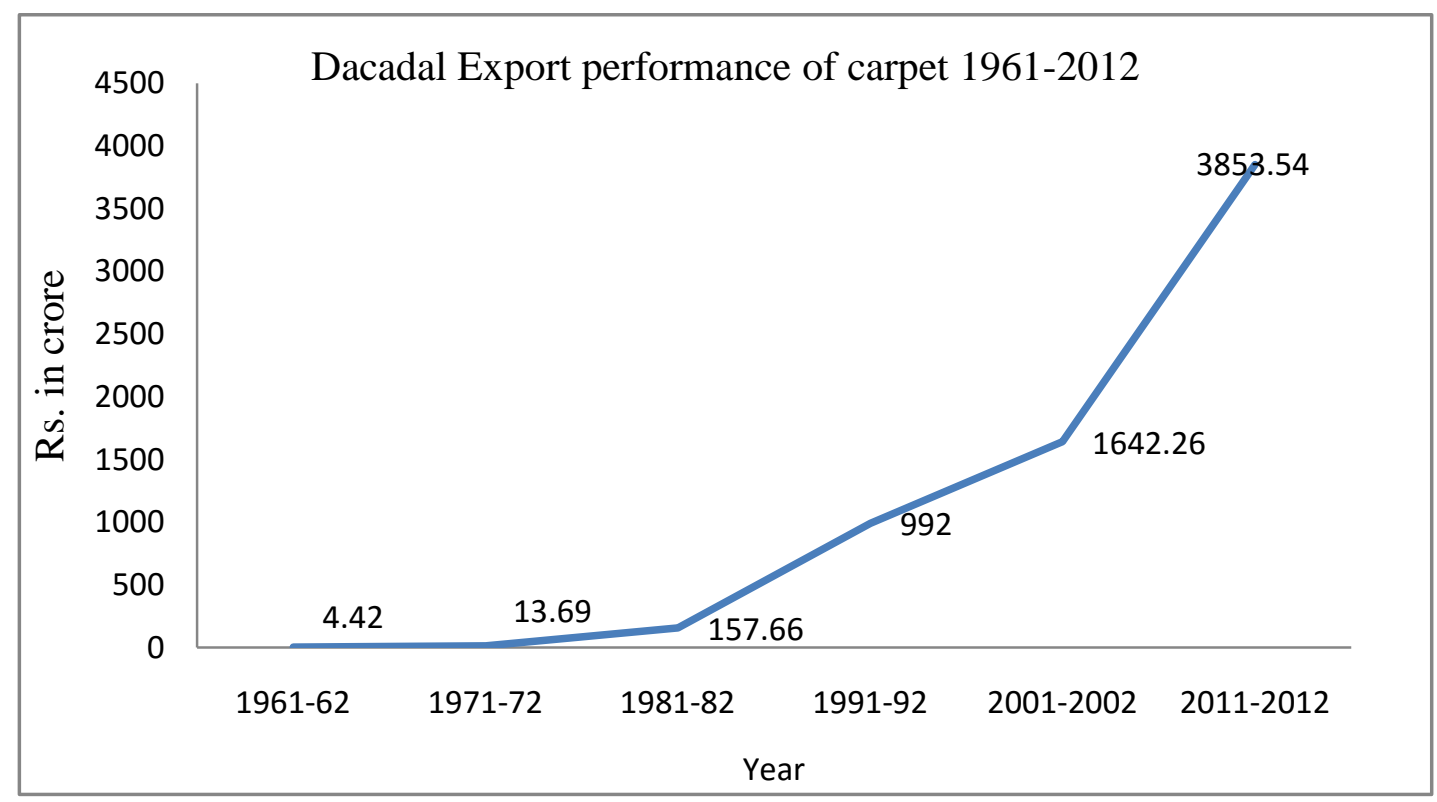

Source:Ministry of Textile, Government of India. 
Table3 Carpet Export from India in terms of Value (Rs. In crore) from the year 2000-01 to 2015-16

\begin{tabular}{|c|c|}
\hline Year & Export of carpet in terms of Value ( Rs. In Crore) \\
\hline $2000-01$ & 3791.27 \\
\hline $2001-02$ & 1642.26 \\
\hline $2002-03$ & 1917.39 \\
\hline $2003-04$ & 3559.65 \\
\hline $2004-05$ & 2727.64 \\
\hline $2005-06$ & 3546.38 \\
\hline $2006-07$ & 6274.02 \\
\hline $2007-08$ & 3766.67 \\
\hline $2008-09$ & 3506.37 \\
\hline $2009-10$ & 7273.04 \\
\hline $2010-11$ & 4777.64 \\
\hline $2011-12$ & 3853.54 \\
\hline $2013-14$ & 7110.42 \\
\hline $2014-15$ & 8441.95 \\
\hline $2015-16$ & 6641.23 \\
\hline
\end{tabular}

Source: Ministry of Textile, Government of India.

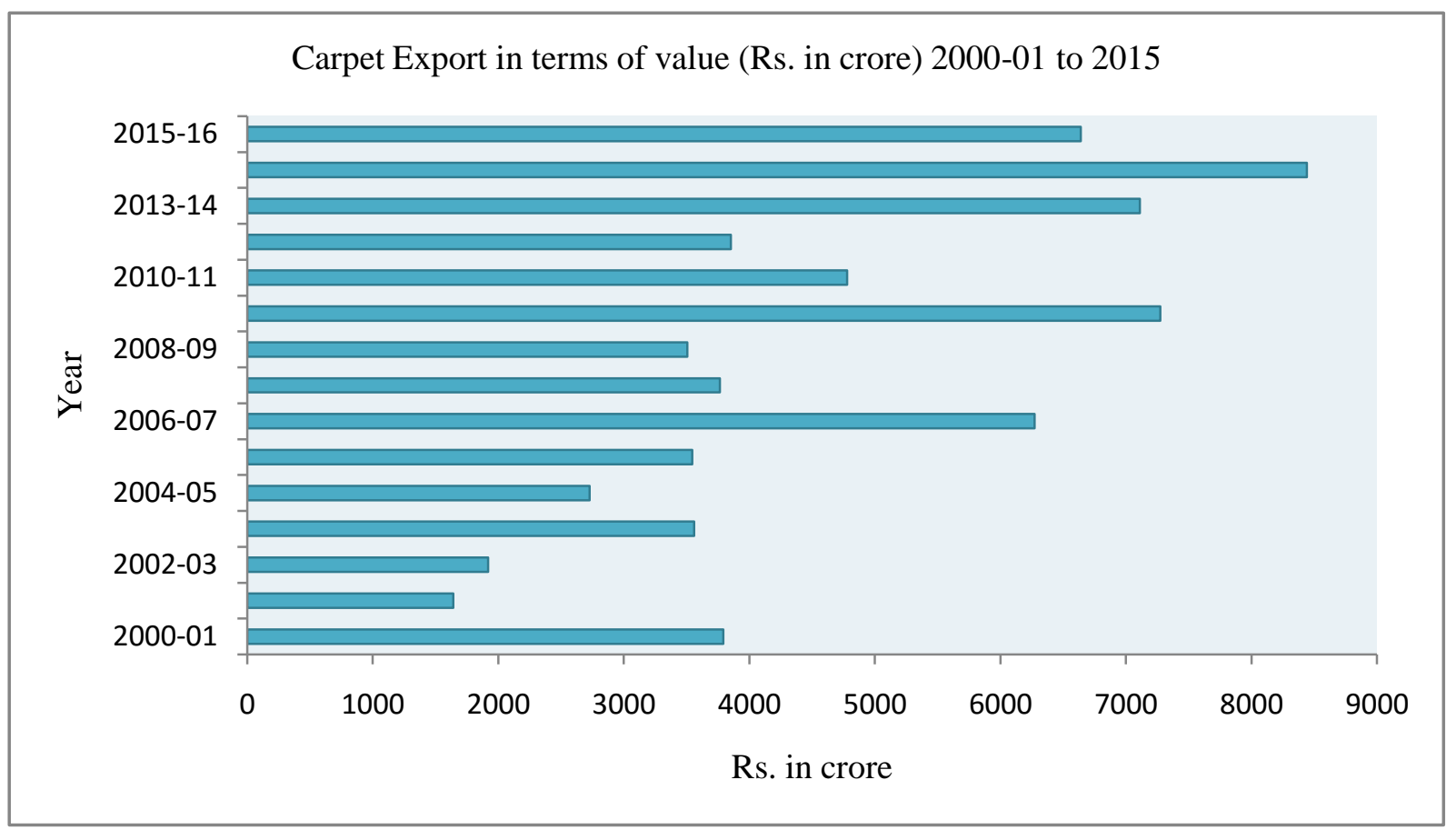

Source: Ministry of Textile, Government of India.

Fig.3 Carpet Export in terms of value from the year 2000-2001 to 2015-2016 


\section{The Global Share of Indian Carpets}

Indian carpet are famous the world over with his magnificent designs and heart winning workmanship, it has been able to capture the world export market and to make mark in the global carpet market .India has made remarkable progress in export market. Handmade woolen carpets, tufted carpets, staple synthetic carpets handmade woolen durries are some of the types for which there is a huge market demand in the European and American market.

The handmade carpet is an important foreign exchange earner for our country, besides providing employment to million workers. The current trend of handmade floor covering is estimated to be around US\$ 2.56 Billion (carpet Council Magazine Feb.2012.pg.11) .India ranks number one in terms of value as well as in volume of exports of handmade carpets. The major competition to the export of handmade carpet is coming from Iran, Pakistan and Nepal. Carpet export increased from US\$ 50 million in 20072008.During the year 2008-9\&2009-10 the export of handmade carpets \& other floor covering declined by $23.15 \%$ and 7.51 respectively. The export of handmade carpets and other floor coverings have increased during the year $2011-12$ by $23.61 \%$ in US $\$$ terms.

India has around 35\% share (diagram1) of the world markets for handmade carpets and floor covering out of which India's export to US accounts for about 39.25\% of total exports. It is estimated that India's export can be doubled if it increase it share in the world floor covering market by $3.5 \%$ India, Iran, China, Nepal are the key player in the global carpet trade. Iran accounts for about 20-255 of total export. China contributes about 20\% (of Machine market) and Nepal for near 10\% among the exporting country. Other significant importers are including Turkey, Afghanistan, and Pakistan. Europe and America are the chief importers accounting for almost $95 \%$ of total carpet imports. In Europe Germany alone takes over $40 \%$ of global import.

India weaves in its own specialized way that makes its carpet unique in all respect. The marvelous design and magical colour blend make it more precious. The trained traditional crafts man weaves the masterpiece that astonished the world and brought the attention of world market towards Indian carpet. The

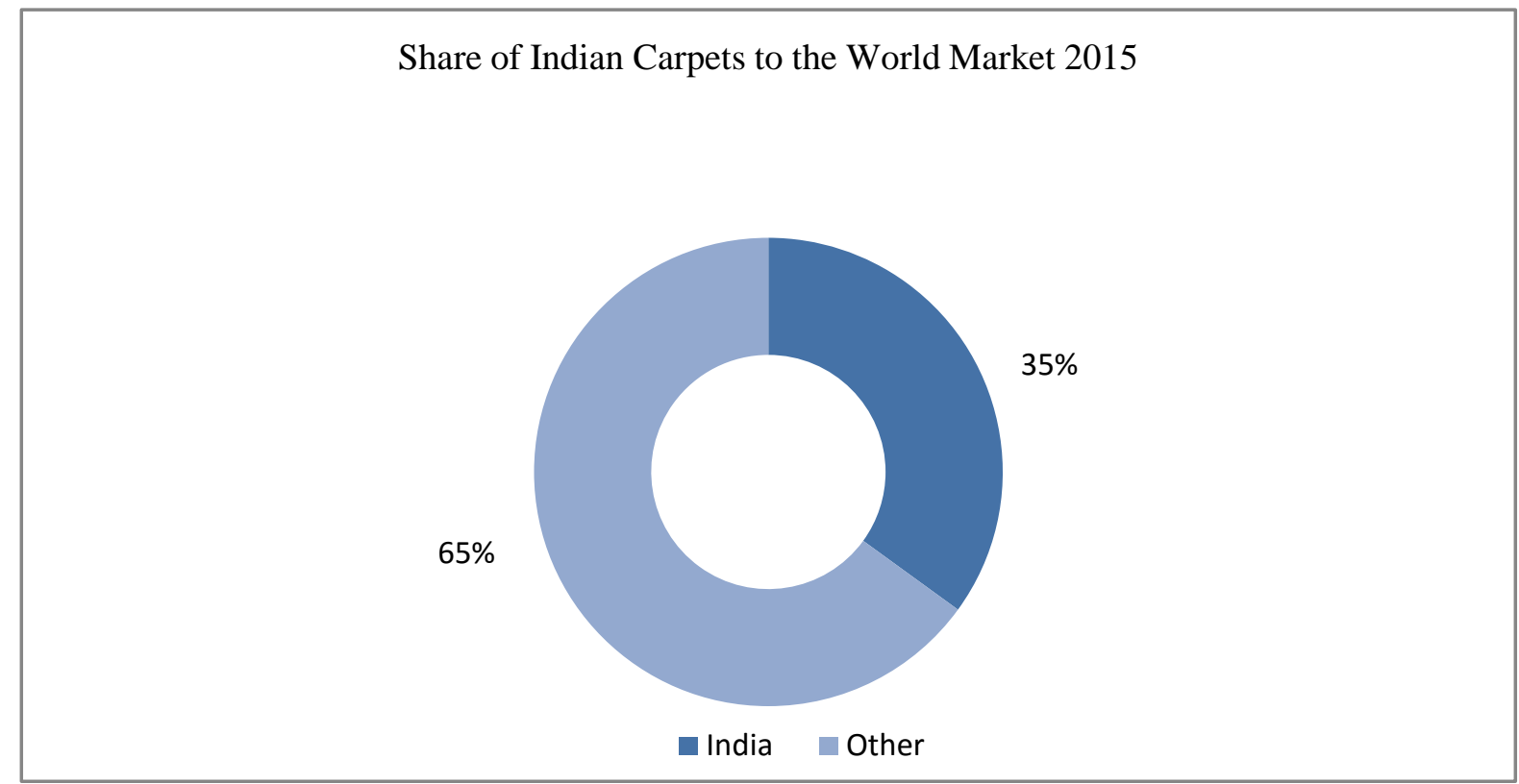

Source: Carpet Export Promotion Council.

Diagram.1.Share of Indian Handmade carpets and floor covering to the world market 
Table 4 shows the export of handmade carpet of India to the different countries. The largest share of carpet export among this country is Germany. The value of export to the Germany is 656 (Rupees in crore) in the year 2012-13 followed by Australia (179.42 Rs. crore), Canada (118.81Rs. crore), Netherland (96.65 Rs. Crore), France (93.34 Rs. Crore), Italy (83.99 Rs. crore), Belgium (72.07 Rs. Crore), Japan (70.12 Rs. Crore), Brazil (64.51 Rs.crore), Sweden ( 60.03 Rs. Crore), Denmark (56.53 Rs. Crore), Norway ( 28.46 Rs. Crore), Austria (26.39 Rs. Crore), Switzerland (19.44), Finland (13.96 Rs. Crore), Argentina (7.24 Rs. Crore). The total export of Handmade carpet to the world in terms of value is 1650.72 (Rs.crore). India leads in the production of handmade carpet in the world. India is the largest exporter of handmade carpet to the world market (Carpet Export Promotion Council, 2012).

Table 4 Export of Indian handmade carpet to different countries in the year 2012-13

\begin{tabular}{|c|c|}
\hline & $2012-13$ \\
\hline Name of country & Rupees (in Crore) \\
\hline Argentina & 7.24 \\
\hline Austarlia & 179.42 \\
\hline Austria & 26.39 \\
\hline Belgium & 72.07 \\
\hline Brazil & 64.51 \\
\hline Canada & 118.81 \\
\hline Denmark & 56.53 \\
\hline Finland & 13.96 \\
\hline France & 96.34 \\
\hline Germany & 656.76 \\
\hline Italy & 83.99 \\
\hline Japan & 70.12 \\
\hline Netherlands & 96.65 \\
\hline Norway & 28.46 \\
\hline Sweden & 60.03 \\
\hline Switzerland & 19.44 \\
\hline Total & 1650.72 \\
\hline
\end{tabular}

Source: Carpet Export Promotion Council 


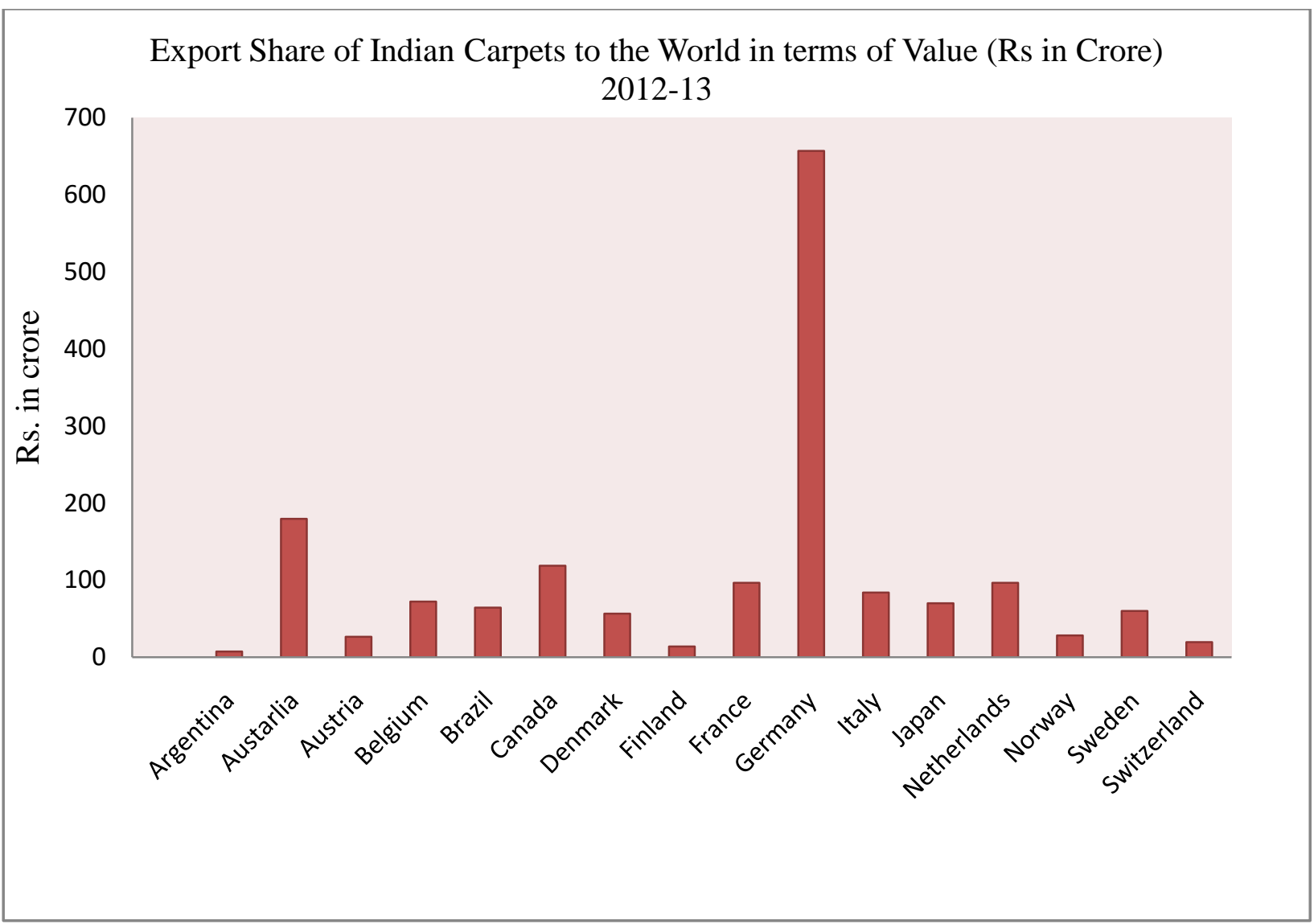

Source: Carpet Export Promotion Council

Fig.4 Countries share of export of carpet from India 2012-13

\section{Hindrance in the path of development of Indian Carpet}

The glorious performance of Indian carpet suffers a lot due to the lack of infrastructure facilities. The major carpet making centers in India accidently develops in the less prosperous region of the country. The artisans that come to the industries are basically from rural areas and lack of good transportation facility they suffer most. The finished product that goes to the port firstly have to face the road transportation. The roadways of rural and semi rural region that connecting to the highway laid in the inappropriate way that are seasonal and create great loss in the monsoon seasons. The leading region in carpet manufacturing in Uttar Pradesh that is Bhadohi- Mirzapur belt (The largest hub of carpet making) suffers greatly due to poor transportation facility. The most important centre of handmade carpets is defamed by its poor road that makes buyer to avoid to visits in the industry. They prefer to stay at the Varanasi and deal the business. This nature of business is decreasing the demand of carpet among the world.

The shortage of electricity supply becomes the major problem that effects on the production of carpet. The power cut problem forced the workers to work only during day time that cause the lower the production. The weavers of carpet industry could not weave carpet during night time. A study of Bano, (2014) reveals that the major belt of carpet manufactured in northern India. Among the northern Indian region, Utter Pradesh is the leading manufacturer. Bhadohi city (known as carpet city) suffers greatly due to poor electricity. The study reveals that this city avails electricity for only 6 hours (average) in a day.

In spite of the foreign exchange earner, carpet industry has the great capacity to provide job opportunity for millions of people. The industry engaged the range of workers either skilled or unskilled. 
The workers involve in the industry dependents heavily on the carpet export performance. The more demand in the market directly effects the million of life of workers. No doubt that engulfs the rural as well as urban unemployed labour and enables them to earn their livelihood with dignity. Due to handicraft industry it is highly unorganized that become the great cause of low wage of workers. The most exploited section of the workers of carpet industry is weavers. They can only earn 150-200 Rs. in a day. The pre carpet making work that performed in the house and mainly done by the women worker are paid very pity amount. In the whole day of labour they can get only 50-60 Rs. in a day (unpublished project, 2012). The low wage of carpet industry workers seems to be the cause that workers are forced to leave their traditional art of carpet making.

The irregular nature of work among the workers of carpet industry is another major cause that hammering in the carpet production.

The carpet weaving is the traditional art of India. The traditional art transform into the modern art in the new era of technology. Due to the large innovation in the market, the carpet of India also demanding the need of technology used in carpet making. The Indian carpets that weave in the traditional region of carpet weaving centers are very far away in the reach of technological innovation. The advancement in the technological innovation in the carpet making can make them more favorite into the world market.

Above all mentioned problem, there are number of other draw backs of carpet industry that become the hurdle in the path of development .There are some pockets of country that is manufacturing world class carpet. There is lack of awareness among the carpet weavers about government scheme that has introduced for their betterment.

\section{Suggestions}

Indian carpet industry is primarily rural based labour intensive and handicraft industry. There are some specific pockets in India. All regions have achieved its own specialty of glorious and unique quality in carpet making. Uttar Pradesh has leading position in the term of manufacturing and export. There should encourage the other state to producing the carpet weaving. The migrant nature of weavers should be checked by providing them. There should be a good rate of wage provided to the workers so, they can sustain their better life. It is following the traditional pattern of carpet weaving. The weavers are dependent on the elementary tools while weaving carpet so, machines of new technology should be introduced. The introduction of machine would enhance the productivity and attractiveness of Indian carpet to the world. There should be connectivity of the carpet producing region with highways that connect the small cities of carpet manufacturing region to big cities. Each region of carpet making industry should have provided the exposure to the world.

\section{Conclusion}

The unique art of carpet weaving done by the skilled weavers produced unmatched quality that raised the attention of the world. Handicrafts industry proves its great role in the economic development. The above study shows the export performance of carpet industry that how it helps in the economic development and becomes the prime agent in the path of development of a country. Indian handmade carpet is probably the unique among the other cottage industry. It is contributing the immense value of foreign currency to the country that strengthens our economy. The carpet industry experienced the positive trend of growth since 1961.This period is very much crucial because that is the period of stiff competition over the world market. The Indian handmade carpet has proved it efficiency to compete to the world due to its unique weave. The ever increasing growth in terms of value of export indicates the high potential of sustainability of this industry in coming future. This industry has a capacity to employee the million of rural unemployed artisans and becomes the best instrument of removing the regional disparity from the country. 


\section{References}

Bano, R. and Fatima, N.(2014). Role of small scale industry and women empowerment: A case study in carpet industry of Bhadohi district, U.P, IJMIE, 4(3), 152

Gito, P. and Kumar, C. (2014). Export market's segmentation performance and marketing of Indian carpet industry: A BCG matrix approach, Pacific Business Review International, 6(11), 1-3.

Judy, A. (1994). The tufted carpet in Britain: Its rise from bottom of the pile. Journal of design history, 7(3), 205-21

Patton, R.L. (1997). A world of opportunity within the tufting empire: Labour relation in North Georgia's carpet industry, 1965-1975.The Georgia historical quarterly, 81(20)

Seyf, A.(1992) .The carpet trade and economy of Iran. British institute of Persian Studies, (9), 23-29.

Singh, S. (1979). Organization of the carpet industry of Bhadohi. Economic and Political weekly, 14(21), 69-71.

Sinha, S. (1982). India and the international market in hand knotted carpets. Economic and political weekly, 17(48), 129-144.Sinha, S. (1989). Development impact of silk production: A wealth of opportunities. Economic and Political weekly, 24(31), 157-163

Shirma, S.K. (2013). Growth of handmade carpet industry. Carpet council news, 5(11), 20.

Shirma, S.K. (2013). Country wise export of handmade carpets. Carpet council news. 5(11), 17. 